\title{
ANALISIS PARITAS IBU DENGAN KEJADIAN BERAT BADAN LAHIR RENDAH DI RUMAH SAKIT PUSRI PALEMBANG
}

\author{
Rosmiarti \\ Sekolah Tinggi Ilmu Kesehatan Muhammadiyah Palembang \\ A B S T R A K
}

Informasi Artikel :

Diterima : April 2018

Disetujui : Mei 2018

Dipublikasikan : Juni 2018

*Korespondensi Penulis : rosmiarti_5474@yahoo.com
Berat badan lahir rendah (BBLR) adalah bayi dengan berat badan lahir kurang dari 2500 gram. WHO memperkirakan hampir semua (98\%) dari 5 juta kematian neonatal terjadi di negara berkembang. Menurut data dinas kesehatan kota Palembang, angka kelahiran BBLR tahun 2008 sebanyak 213 per 1.000 kelahiran hidup dan pada tahun 2009 sebanyak 203 per 1.000 kelahiran hidup. Penyebab BBLR adalah kelahiran prematur, paritas ibu, umur ibu, faktor plasenta, faktor janin dan lingkungan. Penelitian ini bertujuan untuk mengetahui hubungan paritas ibu dengan kejadian BBLR di Rumah Sakit Pusri Palembang Tahun 2017. Desain penelitian ini adalah survai analitik dengan pendekatan cross sectional dimana variabel yang diteliti meliputi paritas ibu. Populasi penelitian ini adalah seluruh ibu bersalin di Rumah Sakit Pusri Palembang tahun 2017 yang berjumlah 553 orang dengan besar sampel penelitian sebanyak 240 orang yang diambil dengan teknik acak sistematik, instrumen penelitian yaitu check list. Analisa data dilakukan secara univariat dan bivariat. Hasil penelitian ini menunjukan dari 240 ibu didapatkan kejadian BBLR 142 orang $(59,2 \%)$ yang memiliki paritas risiko tinggi 32 orang dengan kejadian BBLR $(87,5 \%)$ sedangkan umur ibu risiko tinggi 123 orang dengan kejadian BBLR ( 51,2\%). Dari statistik uji Chi-Square yang membandingkan $p$ value dengan tingkat kemaknaan $\alpha=0,05$ menunjukan bahwa ada hubungan yang bermakna antara paritas ibu $p$ value $(0,00)$ dengan kejadian BBLR di Rumah Sakit Pusri Palembang Tahun 2017. Dari hasil penelitian ini dapat disimpulkan bahwa ibu dengan paritas dan risiko tinggi lebih banyak melahirkan bayi dengan BBLR dibandingkan dengan risiko rendah.

Kata Kunci

: paritas, BBLR

\begin{abstract}
ABSTRACK
Low birth weight (LBW) is a baby with a birth weight of less than 2500 grams. WHO estimates that almost all (98\%) of 5 million neonatal deaths occur in developing countries. According to Palembang city health office data, the birth rate of $L B W$ in 2008 was 213 per 1,000 live births and in 2009 as many as 203 per 1,000 live births. The causes of LBW are premature birth, maternal parity, maternal age, placental factors, fetal factors and the environment. This study aims to determine the relationship of mother parity with the occurrence of LBW at Pusri Palembang Hospital Year 2017. The design of this study is an analytical survey with cross sectional approach where the variables studied include parity of the mother. The population of this study were all maternal mothers at Pusri Palembang Hospital in 2017, which amounted to 553 people with a large sample of 240 samples taken by systematic random technique, research instrument that is check list. Data analysis was done univariat and bivariate. The results of this study showed that from 240 mothers, there was an occurrence of BBLR 142 people (59.2\%) who had high risk parity of 32 people with $L B W$ incidence $(87.5 \%)$ while the high risk maternal age was 123 people with $L B W$ incidence $(51,2 \%)$. From Chi-Square test statistic that compare $p$ value with significance level $\alpha=0,05$ indicate that there is significant relation between mother parity $p$ value $(0,00)$ with incidence of BBLR at Pusri Palembang Hospital 2017. From this research result it was concluded that mothers with parity and high risk were more likely to deliver babies with $L B W$ than low risk.
\end{abstract}

Keyword : Parity, Low Birth Weight 


\section{PENDAHULUAN}

Berat badan lahir rendah (BBLR) adalah bayi dengan berat badan lahir kurang dari 2500 gram.

Berat Badan Lahir Rendah (BBLR) adalah bayi yang lahir dengan berat badan 2500 gram atau kurang tanpa memerhatikan usia kehamilan.

BBLR sendiri dapat dibagi menjadi dua golongan, bayi dengan berat badan lahir sangat rendah (BBLSR) yaitu dengan berat lahir 10001500 gram dan berat badan lahir amat sangat rendah (BBLASR) yaitu dengan berat lahir kurang 1000 gram.

Menurut WHO pada tahun 2010 Angka Kematian Bayi (AKB) di dunia masih cukup tinggi yaitu 54 per 1000 kelahiran hidup. Penyebab kematian antara lain BBLR $(38,94 \%)$, Asfiksia neonaturum (27,97\%), Infeksi yang meliputi sepsis neonaturum $(5,68 \%)$, Pneumonia $(5,68 \%)$ dan kelainan bawaan $(4,04 \%)$ (Widiyastuti dkk, 2009).

Berdasarkan hasil pengumpulan data kesehatan yang ada di Indonesia yang berasal dari fasilitas pelayanan kesehatan, Angka Kematian Bayi (AKB) sebesar 23 per 1000 kelahiran hidup. Penyebab kematian antara lain BBLR $(32,4 \%)$, Asfiksia (35,9\%), Sepsis (12\%), Kelainan Kongenital $(18,1 \%)$, dan Pneumonia $(15,4 \%)$ (Riskesdas, 2015).

Penyebab terbanyak terjadinya Berat Badan Lahir Rendah (BBLR) secara umum bersifat multifaktorial, sehingga kadang mengalami kesulitan untuk melakukan tindakan pencegahan. Namun, penyebab terbanyak terjadinya bayi berat badan lahir rendah adalah kelahiran prematur. Semakin muda usia kehamilan semakin besar risiko jangka pendek dan jangka panjang dapat terjadi, faktor ibu yang lain adalah umur, paritas dan lain-lain, faktor plasenta seperti molahidatidosa, plasenta yang lepas, serta faktor janin juga merupakan penyebab terjadinya BBLR (Sulistyorini, 2014).

\section{METODOLOGI PENELITIAN}

Metode penelitian ini menggunakan survey analitik yaitu penelitian yang mencoba menggali bagaimana dan mengapa fenomena kesehatan itu terjadi. Rancangan pada penelitian ini adalah dengan pendekatan Cross Sectional yaitu suatu penelitian (survey) analitik untuk mempelajari dinamika korelasi antara faktor-faktor risiko dengan efek, dengan cara pendekatan, observasi atau pengumpulan data sekaligus pada waktu yang bersamaan. Tehnik pengambilan sampel menggunakan tehnik Random Sampling. Analisis penelitian ini menggunakan Analisis Univariate.

Bayi Berat Lahir Rendah (BBLR) bayi dengan berat lahir kurang dari 2500 gram tanpa memandang usia gestasi. BBLR dapat terajadi pada bayikurang bulan $(<37$ minggu) atau pada bayi cukup bulan (Pudjiaji, dkk., 2014).

Paritas adalah frekuensi ibu pernah melahirkan anak baik lahir hidup maupun lahir mati (Sarwono, 2014).

Berdasarkan hasil penelitian Astuti (2014), hasil analisis univariat didapatkan ibu yang memiliki paritas tinggi sebesar 246 responden $(71,1 \%)$ dan pada ibu yang memiliki paritas rendah sebesar 100 responden (28,9\%). Dari hasil uji Chi-Square menunjukkan ada hubungan antara paritas ibu bersalin dengan kejadian BBLR (Astuti, 2014).

\section{HASIL PENELITIAN}

Tabel 1

Distribusi Frekuensi Ibu Bersalin Berdasarkan Kejadian Berat Badan Lahir Rendah (BBLR) di Rumah Sakit Pusri Palembang Tahun 2017

\begin{tabular}{llcc}
\hline No. & BBLR & Frekuensi & Persentase (\%) \\
\hline 1. & Ya & 142 & 59,2 \\
\hline 2. & Tidak & 98 & 40,8 \\
\hline \multicolumn{2}{c}{ Total } & 240 & 100 \\
\hline
\end{tabular}

Tabel 1 diatas, yang menunjukkan ibu yang melahirkan bayi dengan BBLR adalah 142 orang $(59,2 \%)$, sedangkan ibu yang melahirkan bayi dengan tidak BBLR sebanyak 98 orang $(40,8 \%)$.

Tabel 2 Distribusi Frekuensi Ibu Bersalin Berdasarkan Paritas Ibu di Rumah Sakit Pusri Palembang Tahun 2017

\begin{tabular}{cccc}
\hline No. & Paritas & Frekuensi & $\begin{array}{c}\text { Persentase } \\
(\boldsymbol{\%})\end{array}$ \\
\hline 1. & Paritas Tinggi & 123 & 51,2 \\
\hline 2. & Paritas Rendah & 117 & 48,8 \\
\hline & Total & 240 & 100 \\
\hline
\end{tabular}

Tabel 2 diatas, yang menunjukan ibu yang memiliki paritas tinggi adalah 123 orang $(51,2 \%)$, sedangkan yang memiliki paritas rendah adalah sebanyak 117 orang $(48,8 \%)$. 


\section{Tabel 3 Hubungan Paritas Ibu Bersalin dengan Kejadian BBLR di Rumah Sakit PusriPalembang Tahun 2017}

\begin{tabular}{|c|c|c|c|c|c|c|c|c|c|}
\hline \multirow{3}{*}{$\begin{array}{l}\mathbf{N} \\
\mathbf{o}\end{array}$} & \multirow{3}{*}{ Paritas } & \multicolumn{4}{|c|}{ BBLR } & \multicolumn{2}{|c|}{ Total } & \multirow{3}{*}{$O R$} & \multirow[b]{3}{*}{$p$ value } \\
\hline & & \multicolumn{2}{|c|}{ Ya } & \multicolumn{2}{|c|}{ Tidak } & \multirow{2}{*}{$\mathbf{N}$} & \multirow{2}{*}{$\%$} & & \\
\hline & & $\mathbf{n}$ & $\%$ & $\mathrm{n}$ & $\%$ & & & & \\
\hline \multirow[t]{2}{*}{1} & Paritas & 85 & 69,1 & 38 & 30,9 & 123 & 100 & \multirow{4}{*}{2.355} & \multirow{4}{*}{$\mathbf{0 , 0 2}$} \\
\hline & Tinggi & & & & & & & & \\
\hline \multirow[t]{2}{*}{2} & $\begin{array}{l}\text { Paritas } \\
\text { Rendah }\end{array}$ & 57 & 48,7 & 60 & 51,3 & 117 & 100 & & \\
\hline & Total & 142 & 59,2 & 98 & 40,8 & 240 & 100 & & \\
\hline
\end{tabular}

Tabel 3 diatas menunjukan dari 123 orang ibu yang memiliki paritas tinggi, terdapat 85 orang $(69,1 \%)$ yang melahirkan bayi dengan BBLR. Sedangkan ibu dengan paritas rendah sebanyak 117 orang dan 57 orang $(48, \%)$ ibu melahirkan bayi dengan BBLR.

\section{PEMBAHASAN}

Berat Badan Lahir Rendah (BBLR) adalah bayi yang baru lahir yang berat badannya saat lahir kurang dari 2500 gram (sampai dengan 2499 gram) (Sarwono Prawihardjo, 2011).

Berikut ini adalah faktor-faktor yang berhubungan dengan bayi BBLR secara umur yaitu sebagai berikut:

1. Faktor ibu

a. Penyakit: Perdarahan antepartum, anemia berat, hipertensi, preeklamnsi berat, eklamnsi, infeksi selama kehamilan (infeksi kandung kemih dan ginjal). Menderita penyakit seperti malaria, infeksi menular seksual dan HIV / AIDS.

b. Umur: < 20 tahun, umur $>35$ tahun dan multigravida yang jarak kelahirannya terlalu dekat.

c. Keadaan sosial seperti: Golongan sosial ekonomi rendah dan perkawinan yang tidak syah.

d. Sebab lain seperti: Ibu yang perokok, peminum alkohol dan pecandu narkotika.

2. Faktor Janin

a. Hidramnion

b. Kehamilan ganda

c. Kelainan kromosom

d. Radiasi infeksi janin kronik

Menurut Proverawati (2014), Bayi yang lahir dengan berat badan rendah mempunyai ciriciri:

1. Umur kehamilan < 37 minggu

2. Berat badan $<2.500$ gram

3. Panjang badan $\leq 46 \mathrm{~cm}$ dan lingkar kepala $<33$

$\mathrm{cm}$
4. Rambut lanugo masih banyak

5. Jaringan lemak subkutan tipis atau kurang

6. Tulang rawan daun telinga belum sempurna pertumbuhannya

7. Tumit mengkilap dan telapak kaki halus

8. Genetalia belum sempurna, labia minora belum tertupi oleh labia mayora, klitoris menonjol (pada bayi perempuan). Testis belum turun kedalam skrotum, pigmentasi dan regue pada skrotum kurang (pada bayi laki-laki)

9. Tonus otot lemah sehingga bayi kurang aktif dan pergerakannya lemah

10.Fungsi syaraf yang belum atau tidak efektif dan tangisnya lemah

11.Jaringan kelenjar mamae masih kurang akibat pertumbuhan otot dan jaringan lemak masih kurang

12. Verniks kaseosa tidak ada atau sedikit bila ada.

13.Paritas merupakan faktor sangat berpengaruh terhadap hasil konsepsi, perlu diwaspadai seorang ibu pernah hamil atau melahirkan sebanyak 4 kali atau lebih, karena hal tersebut akan berdampak pada status kesehatan ibu seperti anemia, kurang gizi, kekendoran dinding perut dan rahim, serta perut ibu tampak menggantung, (Rochyati, 2010).

Penelitian ini sesuai dengan penelitian Astuti (2014), hasil analisis univariat didapatkan ibu yang memiliki paritas tinggi sebesar 246 responden $(71,1 \%)$ dan pada ibu yang memiliki paritas rendah sebesar 100 responden ( 28,9\%). Dari hasil uji Chi-Square menunjukkan ada hubungan antara paritas ibu bersalin dengan kejadian BBLR (Astuti, 2014).

\section{KESIMPULAN}

Berdasarkan uraian dan pembahasan hasil penelitian yang telah dilakukan dapat ditarik kesimpulan sebagai berikut :

1. Diketahui distribusi frekuensi terjadinya berat badan lahir rendah (BBLR) sebanyak 142 orang (59,2\%) di Rumah Sakit Pusri Palembang Tahun 2017.

2. Diketahui distribusi frekuensi paritas ibu bersalin dengan paritas resiko tinggi sebanyak 123 orang $(51,2 \%)$ dan paritas resiko rendah sebanyak 117 orang $(48,8 \%)$ di Rumah Sakit Pusri Palembang Tahun 2017.

3. Diketahui hubungan paritas ibu dengan kejadian berat badan lahir rendah (BBLR) sebanyak 240 orang (100\%) di Rumah Sakit Pusri Palembang Tahun 2017. 


\section{DAFTAR PUSTAKA}

Dinas Kesehatan Sumatera Selatan Palembang. 2015. Profil Kesehatan Palembang

Depkes RI. 2015. Profil Kesehatan Republik Indonesia

Djitowiyono, S. Weni Kristianasari. 2011. Asuhan Keperawatan Neonatal dan Anak. Yogyakarta : Muha Medika

Hidayat, A. A. 2007. Metode Penilitian Kebidanan Teknis Analisis Dat. Jakarta : Salemba

IDAI. 2009. Manajemen Masalah Bayi Baru Lahir untuk Dokter, Bidan dan Perawat di Rumah Sakit : Depkes RI

Joeharno, Astuti. 2014. Berat Badan Lahir Rendah.(htt://www.blogspot.co.id diakses 15 september 2014).

Mariyanti, Dwi, Sujianti, Tri Budiarti. 2011. Buku Ajar Neonatus, Bayi dan Balita. Jakarta : Trans Media

Muchtar, M., Rochyati. 2007. Faktor Risiko Terjadinya Bayi Berat Lahir Rendah di RSB Mulia Makasar Tahun 2007. Fakultas Kedokteran UMI

Notoatmodjo, S. 2012. Metodologi Penilitian Kesehatan. Jakarta: Rineka Cipta

Notoatmodjo, S. 2012. Metodologi Penilitian Kesehatan. Jakarta: Rineka Cipta

Pantiawati, Ika. 2012. Bayi dengan berat badan lahir rendah $(B B L R)$. Yogyakarta: Muha Medika

Proverawati, Ismawati. 2014. Berat Badan Lahir Rendah (BBLR).

Yogyakarta : Trans Media

Prawirohardjo, Sarwono. 2007. Ilmu Kebidanan. Jakarta : Yayasan Bina Pustaka Sarwono

Rumah Sakit Muhammadiyah Palembang. 2014. Profil Kesehatan Palembang

Suradi, Anwar, Aprianyanti. 2006. Hubungan Paritas dengan BBLR. .(htt://www.blogspot.co.id diakses 15 september 2014).

Zaenab, Husin. 2006. Berat Badan Lahir Rendah. Jakarta : Balai Pustaka. 
